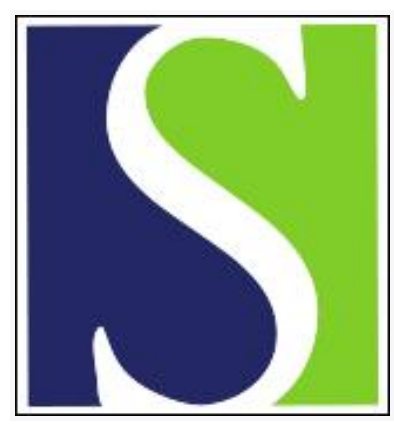

Scand J Work Environ Health 1993;19(2):132-134

https://doi.org/10.5271/sjweh.1495

Issue date: 01 Apr 1993

Chromosome aberrations in peripheral lymphocytes of workers employed in the plywood industry.

by Kurttio P, Norppa H, Jarventaus H, Sorsa M, Kalliokoski P

Affiliation: Department of Environmental Sciences, University of Kuopio, Finland.

This article in PubMed: www.ncbi.nlm.nih.gov/pubmed/8316781

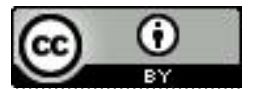




\title{
Chromosome aberrations in peripheral lymphocytes of workers employed in the plywood industry
}

\author{
by Päivi Kurttio, MSc, ${ }^{1}$ Hannu Norppa, PhD, ${ }^{2}$ Hilkka Järventaus, ${ }^{2}$ Marja Sorsa, $\mathrm{PhD},{ }^{2}$ \\ Pentti Kalliokoski, PhD, ${ }^{2}$
}

\begin{abstract}
KURTTIO P, NORPPA H, JÄRVENTAUS H, SORSA M, KALLIOKOSKI P. Chromosome aberrations in peripheral lymphocytes of workers employed in the plywood industry. Scand $J$ Work Environ Health 1993;19:132 - 4. Workers employed in sawmills and in the manufacture of plywood are exposed to potentially mutagenic chemical aromatic emissions from wood. However, very little is known about the exposure to these natural wood components. In an attempt to determine whether such exposure could have clastogenic effects, a group of 13 male nonsmoking employees mainly from the beginning of the wood-processing line of three plywood mills and 15 matched nonsmoking referents were studied for chromosome aberrations in blood lymphocytes. A statistically significant elevation of the frequency of cells with chromatid-type breaks (mean $2.1 \%$ ), as compared with the corresponding frequency of the referents (mean $1.0 \%$ ), was observed for the lymphocytes of the wood workers. These results lend support to previous studies which suggested that wood-drying fumes may be carcinogenic.
\end{abstract}

Key terms: clastogenicity, cytogenetic biomonitoring, mechanical wood processing, terpenes.

Workers in the plywood industry are exposed to various suspected or known carcinogens (1). In addition, complex uncharacterized emissions from mechanical wood processing have been reported to cause coughing, throat irritation, and a slight decline in lung function $(2,3)$.

In a Finnish case-referent study (1), an association was found between respiratory cancer and work in the mechanical wood industry. Exposure to terpenes and other products from the heating of coniferous timber was significantly associated with an increased risk of respiratory cancer when the duration of exposure exceeded five years. In addition, exposure to pesticides and phenol seemed to increase the risk. A similar association had not been observed for exposure to wood dust or formaldehyde $(1,4)$. Wood workers who are in contact with fresh wood are also suspected to be at an elevated risk for chronic lymphatic leukemia, while no such relation has been found for persons working with dried wood (5). Fumes from spruce and birch were observed to be mutagenic in the Ames' Salmonella mammalian microsome assay, but no mutagenicity was observed with wood dusts of these species (6). These studies suggest that compounds emitted from fresh wood or formed from it by heating may be a carcinogenic hazard to exposed humans.

1 Department of Environmental Sciences, University of Kuopio, Kuopio, Finland.

2 Department of Industrial Hygiene and Toxicology, Institute of Occupational Health, Helsinki, Finland.

Reprint requests to: Professor $\mathrm{P}$ Kalliokoski, Department of Environmental Sciences, University of Kuopio, PO Box 1627, FIN-70211 Kuopio, Finland.
In our study, workers exposed to natural emissions from wood (pine, spruce, and birch) processing during veneer production were examined for chromosome aberrations in their blood lymphocytes.

\section{Subjects and methods}

Fifteen male plywood workers [mean age 47 (SD 5) years] from three factories in eastern Finland formed the exposed group. They had been employed in veneer production for an average of 20 (SD 7) years and were selected from nonsmokers working primarily at the beginning of the process in tasks such as barking, cutting, and peeling logs (table 1). Thus they were supposedly exposed to the heating products and other compounds emitted from wood. Five of the workers (numbers 11-15) were employed in activities such as loading (gluing department), pressing, sawing, and sorting plywood, with potential exposure to glues and formaldehyde, in addition to the emissions from wood. The exposed workers were employed at wood processing mills that had earlier been included in a study of chemical exposure in the plywood industry (7).

The referents [mean age 47 (SD 5) years] were men who were nonsmokers and matched for age with the exposed workers. They were from the same town and were employed by a municipal energy plant, a loading company, or a health care center.

Before the blood sampling, all of the subjects filled out a questionnaire which included questions about their age, present and previous jobs, chemical exposures, diseases, hospitalizations, X-ray exposures, recent virus infections, medication, recent vaccinations, alcohol consumption, diets, and present and 
previous smoking habits. The questionnaire confirmed that all of the persons studied, except one exposed worker, were nonsmokers. In the final results, the only smoker and another exposed person whose lymphocyte cultures did not yield enough metaphases for analysis were excluded. The questionnaire revealed no other condition or exposure among the subjects that would be known to influence chromosome aberration analysis.

To minimize possible interference by culture conditions, we collected all of the blood samples and used them for the lymphocyte cultures during a sin- gle day. The venous blood samples were collected into tubes containing lithium heparin (Terumo Venoject, Leuwen, Belgium). The whole-blood lymphocyte cultures, two from each sample, were set up as previously described (8) and were cultivated for $48 \mathrm{~h}$. The cells were harvested, fixed, put on slides, and stained as reported earlier $(9,10)$. The duplicate cultures were united at harvest. The slides were coded, and metaphases were located with the use of automated metaphase finding (Cytoscan Cytogenetics Image Analysis System CS2, Warrington, United Kingdom). The found metaphases were recalled with

Table 1. Chromosome aberrations in peripheral lymphocytes of the workers employed in veneer production and the referents.

\begin{tabular}{|c|c|c|c|c|c|c|c|c|}
\hline \multirow{3}{*}{$\begin{array}{l}\text { Person } \\
\text { number }\end{array}$} & \multirow{3}{*}{$\begin{array}{c}\text { Age } \\
\text { (years) }\end{array}$} & \multirow{3}{*}{$\begin{array}{l}\text { Duration } \\
\text { of work } \\
\text { in mill } \\
\text { (years) }\end{array}$} & \multirow{3}{*}{$\begin{array}{l}\text { Tasks in } \\
\text { mill }\end{array}$} & \multicolumn{5}{|c|}{ Cells with chromosome aberrations (\%) } \\
\hline & & & & \multirow[b]{2}{*}{ Gaps } & \multirow{2}{*}{$\begin{array}{l}\text { Chromatid- } \\
\text { type }\end{array}$} & \multirow{2}{*}{$\begin{array}{l}\text { Chromo- } \\
\text { some- } \\
\text { type }\end{array}$} & \multicolumn{2}{|c|}{ Total } \\
\hline & & & & & & & $\begin{array}{c}\text { Gaps } \\
\text { excluded }\end{array}$ & $\begin{array}{c}\text { Gaps } \\
\text { included }\end{array}$ \\
\hline \multicolumn{9}{|c|}{ Veneer workers } \\
\hline 1 & 51 & 28 & $\begin{array}{l}\text { Operator in } \\
\text { drier plant }\end{array}$ & 0.0 & 3.0 & 1.0 & 4.0 & $4.0^{\mathrm{a}}$ \\
\hline 2 & 44 & 20 & $\begin{array}{l}\text { Operator in } \\
\text { drier plant }\end{array}$ & 0.0 & 4.0 & 1.0 & 5.0 & 5.0 \\
\hline 3 & 49 & 16 & $\begin{array}{l}\text { Controller in } \\
\text { barking plant }\end{array}$ & 1.0 & 3.0 & 2.0 & 5.0 & $6.0^{\mathrm{b}}$ \\
\hline 4 & 44 & 26 & Turner & 0.0 & 2.7 & 0.0 & 2.7 & $2.7^{c}$ \\
\hline 5 & 40 & 13 & Turner & 1.0 & 2.0 & 2.0 & 4.0 & 5.0 \\
\hline 6 & 47 & 19 & $\begin{array}{l}\text { Controller in } \\
\text { barking plant }\end{array}$ & 0.0 & 1.0 & 2.0 & 3.0 & 3.0 \\
\hline 7 & 54 & 23 & $\begin{array}{l}\text { Operator in } \\
\text { drier plant }\end{array}$ & 1.0 & 1.0 & 0.0 & 1.0 & 2.0 \\
\hline 8 & 40 & 15 & $\begin{array}{l}\text { Operator in } \\
\text { turner department }\end{array}$ & 0.0 & 2.0 & 0.0 & 2.0 & 2.0 \\
\hline 9 & 58 & 30 & General operator & 0.0 & 2.1 & 0.0 & 2.1 & $2.1^{d}$ \\
\hline 10 & 55 & 21 & General operator & 0.0 & 1.0 & 1.0 & 2.0 & 2.0 \\
\hline 11 & 46 & 22 & $\begin{array}{l}\text { Controller in } \\
\text { sawing department }\end{array}$ & 1.0 & 3.0 & 1.0 & 4.0 & 5.0 \\
\hline 12 & 41 & 21 & $\begin{array}{l}\text { Loading truck } \\
\text { driver }\end{array}$ & 0.0 & 1.0 & 1.0 & 2.0 & 2.0 \\
\hline $\begin{array}{l}13 \\
14\end{array}$ & $\begin{array}{l}43 \\
50\end{array}$ & 23 & $\begin{array}{l}\text { Operator of press } \\
\text { Quality sorter }\end{array}$ & $\begin{array}{l}0.0 \\
0.0\end{array}$ & $\begin{array}{l}3.0 \\
3.0\end{array}$ & $\begin{array}{l}0.0 \\
3.0\end{array}$ & $\begin{array}{l}3.0 \\
6.0\end{array}$ & $\begin{array}{l}3.0 \\
6.0\end{array}$ \\
\hline 15 & 50 & 22 & Quality sorter & 0.0 & 1.0 & 0.0 & 1.0 & 1.0 \\
\hline Mean & 47 & 20 & & 0.2 & $2.1^{* *}$ & 0.9 & 3.0 & 3.2 \\
\hline
\end{tabular}

\section{Referents}

\begin{tabular}{|c|c|c|c|c|c|c|c|c|}
\hline $1^{e}$ & 44 & . & . & 2.0 & 2.0 & 2.0 & 4.0 & 6.0 \\
\hline 2 & 43 & . & . & 1.0 & 3.0 & 0.0 & 3.0 & 4.0 \\
\hline 3 & 44 & . & . & 0.0 & 0.0 & 0.0 & 0.0 & 0.0 \\
\hline 4 & 49 & $\cdot$ & $\cdot$ & 1.0 & 0.0 & 3.0 & 3.0 & 4.0 \\
\hline 5 & 58 & $\cdot$ & . & 0.0 & 0.0 & 1.0 & 1.0 & 1.0 \\
\hline $6^{e}$ & 48 & $\cdot$ & . & 0.0 & 2.0 & 1.0 & 3.0 & 3.0 \\
\hline 7 & 51 & . & . & 0.0 & 1.0 & 0.0 & 1.0 & 1.0 \\
\hline 8 & 41 & . & . & 0.0 & 0.0 & 3.0 & 3.0 & 3.0 \\
\hline $9^{e}$ & 52 & . & . & 0.0 & 0.0 & 1.0 & 1.0 & 1.0 \\
\hline 10 & 51 & $\cdot$ & . & 0.0 & 2.0 & 1.0 & 3.0 & 3.0 \\
\hline 11 & 42 & . & . & 1.0 & 2.0 & 0.0 & 2.0 & 3.0 \\
\hline 12 & 49 & $\cdot$ & $\cdot$ & 1.0 & 1.0 & 1.0 & 2.0 & 3.0 \\
\hline 13 & 52 & $\cdot$ & $\cdot$ & 0.0 & 1.0 & 0.0 & 1.0 & 1.0 \\
\hline 14 & 41 & . & . & 1.0 & 1.0 & 0.0 & 1.0 & 2.0 \\
\hline 15 & 46 & $\cdot$ & $\cdot$ & 1.0 & 0.0 & 0.0 & 0.0 & 1.0 \\
\hline Mean & 47 & . & . & 0.5 & 1.0 & 0.9 & 1.9 & 2.4 \\
\hline
\end{tabular}

a Five aberrations/100 metaphases.

b A smoker, not included in the means.

c Thirty-seven metaphases found, not included in the means.

d Forty-eight metaphases found.

e Medication for hypertension.

${ }^{*}{ }^{*} \mathrm{P}<0.01$, Mann-Whitney u-test (2-tailed). 
inranking set "off." Using the Cytoscan microscope, a microscopist analyzed 100 metaphases per person for the presence of structural chromosome aberrations.

The mean number of aberrant cells among the exposed and reference groups were statistically compared with the Mann-Whitney u-test (2-tailed).

\section{Results and discussion}

The workers employed in plywood production showed about a two times higher frequency of cells with chromatid-type aberrations than the referents (table 1). The difference was statistically significant $(P<0.01)$. All of the excess aberrations were singlecell chromatid breaks.

An association has been shown in mechanical wood processing between increased risks for respiratory cancers and exposure to pesticides and the heating products of wood (1). The subjects of this study were selected mainly from the beginning of the wood-processing line where exposure to pesticides can be estimated to be insignificant. Therefore, the emissions from wood itself were the most likely cause of the clastogenic effects observed in this study.

The fumes from wood drying consist mostly of monoterpenes (11). The total concentration of airborne monoterpenes during veneer processing has varied from 1 to $30 \mathrm{mg} \cdot \mathrm{m}^{-3}(11,12)$, values far below the Finnish occupational exposure limit of turpentine $\left(560 \mathrm{mg} \cdot \mathrm{m}^{-3}\right)$. The increase in aberrant cells among the plywood workers indicates exposure to clastogenic chemicals. These findings are interesting in light of the results of previous studies in which increased risk for respiratory cancers and chronic lymphatic leukemia were suggested to be caused by work with wood $(1,5)$. In general, increased chromosome aberrations are interpreted as biological effects possibly associated with an elevated risk of cancer $(13,14)$. Action should thus be taken to provide a better characterization of the agents responsible for the observed effect and, subsequently, to decrease the causative exposure.

\section{Acknowledgments}

The authors wish to thank H Halinen, MD, J Rantalainen, MD, Ms A Heinola, and the volunteers for their excellent cooperation during the collection of the blood samples.

This study was financially supported by the Finnish Work Environment Fund.

\section{References}

1. Kauppinen TP, Partanen TJ, Nurminen MM, Nickels JI, Hernberg SG, Hakulinen TR, et al. Respiratory cancer and chemical exposures in the wood industry: a case-control study. Br J Ind Med 1986;43:84-90.

2. Lindberg E. Exposition för sågångor - samband mellan exposition och besvär samt mellan exposition och vissa lungfunktionsvariabler [Exposure to sawmill fumes - connection between exposure and symptoms, as well as between exposure and certain lung functions]. Stockholm: Arbetarskyddsverket, 1979. (Arbete och hälsa 27.)

3. Hedenstierna G, Alexandersson R, Wimander K, Rosén G. Exposure to terpenes: effects on pulmonary function. Int Arch Occup Environ Health 1983;51: $191-8$.

4. Partanen T, Kauppinen T, Nurminen M, Nickels J, Hernberg $\mathrm{S}$, Hakulinen $\mathrm{T}$, et al. Formaldehyde exposure and respiratory and related cancers: a case-referent study among Finnish woodworkers. Scand J Work Environ Health 1985;11:409-15.

5. Flodin V, Fredriksson M, Persson B, Axelson O. Chronic lymphatic leukemia and engine exhausts, fresh wood, and DDT: a case-referent study. Br J Ind Med 1988; $45: 33-8$.

6. Kurttio P, Kalliokoski P, Lampelo S, Jantunen MJ. Mutagenic compounds in wood chip drying fumes. Mutat Res 1990;242:9-15.

7. Kauppinen T. Occupational exposure to chemical agents in the plywood industry. Ann Occup Hyg 1986; 30:19-29.

8. Jantunen K, Mäki-Paakkanen J, Norppa H. Induction of chromosome aberrations by styrene and vinyl acetate in cultured human lymphocytes: dependence on erythrocytes. Mutat Res 1986;159:109-116.

9. Mäki-Paakkanen J, Husgafvel-Pursiainen K, Kalliomäki P-L, Tuominen J, Sorsa M. Toluene-exposed workers and chromosome aberrations. J Toxicol Environ Health 1980;6:775-81.

10. Norppa $\mathrm{H}$, Järventaus $\mathrm{H}$. Induction of chromosome aberrations and sister chromatid exchanges by caprolactam in vitro. Mutat Res 1989;224:333-7.

11. Cronn DR, Truitt SG, Capell MJ. Chemical characterization of plywood veneer dryer emissions. Atmos Environ 1983;17:201-11.

12. Konttinen S, Kurttio P, Raunemaa T, Kalliokoski P. Comparison of methods for analyzing monoterpene concentrations in occupational air. Chemosphere 1989; 19:1483-8.

13. Aitio A, Becking G, Berlin A, Bernard A, Foa V, Kello $\mathrm{D}$ et al, ed. Indicators for assessing exposure and biological effects of genotoxic chemicals: consensus and technological reports. Luxembourg: Commission of the European Communities, International Programme on Chemical Safety (UNEPILO-WHO), World Health Organization Regional Office for Europe, Institute of Occupational Health (Finland), 1988.

14. International Commission for Protection Against Environmental Mutagens and Carcinogens (ICPEMC). Considerations for population monitoring using cytogenetic techniques. Mutat Res 1988;204:379-406.

Received for publication: 29 April 1992 